\title{
ANALISIS KOEFISIEN LIMPASAN PERMUKAAN KOTA MAKASSAR DENGAN METODE COOK
}

\author{
Sudirman Nganro ${ }^{1}$, Slamet Trisutomo ${ }^{2}$, Roland A. Barkey ${ }^{3}$, Mukti Ali ${ }^{2}$
}

Diterima: 17 April 2018

Disetujui: 17 Agustus 2018

\begin{abstract}
Abstrak: Hujan yang jatuh pada Daerah Aliran Sungai akan berubah menjadi aliran di sungai, hal ini disebabkan karena air hujan tidak seluruhnya dapat terinfiltrasi ke dalam tanah, air yang tidak terserap disebut limpasan permukaan. Faktor-faktor yang mempengaruhi limpasan adalah elemen meteorologi dan elemen daerah pengaliran. Penelitian ini bertujuan untuk menghitung koefisien limpasan permukaan dengan menggunakan peta penggunaan lahan dan tutupan lahan Tahun 2017 dan 2050, kemiringan lereng dan jenis tanah sebagai parameter. Metode Cook membagi karakteristik DAS kedalam 4 bagian sebagai parameter untuk menghitung koefisien limpasan yaitu topografi, jenis tanah, vegetasi penutup dan simpanan permukaan. Masing-masing parameter diberi bobot berdasarkan karakteristiknya untuk menghitung koefisien limpasan permukaan yang disimbolkan dengan huruf $\mathrm{C}$. Hasil analisis menunjukkan bahwa pada Tahun 2017 diperoleh nilai $C=0.4734$ dan untuk tahun 2050 $\mathrm{C}=0.4785$. Terjadi selisih sebesar 0.0051 nilai koefisien limpasan antara peta penggunaan lahan dan tutupan lahan Tahun 2017 dan Tahun 2050. Hasil penelitian ini akan dimanfaatkan untuk menghitung debit banjir rancangan pada objek penelitian di Kota Makassar.
\end{abstract}

\section{Kata kunci: Analisis, koefisien limpasan, metode Cook, 2017 dan 2050, Kota Makassar}

Abstract: Rain falling on the Watershed will turn into a stream in the river, this is because the rainwater is not entirely infiltrated into the soil, the unabsorbed water is called surface runoff. Factors affecting runoff are meteorological elements and drainage elements. This study aims to calculate the surface runoff coefficient using land cover maps 2017 and 2050, slope and soil type as parameters. Cook method divides the watershed characteristics into 4 sections as parameters to calculate the runoff coefficient of topography, soil type, vegetation cover and surface deposit. Each parameter is weighted based on its characteristics to calculate the coefficient of surface runoff symbolized by the letter $\mathrm{C}$. The analysis results show that in the year 2017 obtained the value of $C=0.4734$ and for the year $2050 C=0.4785$. There's a difference of 0.0051 coefficient of runoff value between land use map and land cover in 2017 and 2050. The results of this study will be used to calculate the flood discharge design in the object of research in Makassar City.

Keyword: analysis, run off coefficient, cook method, 2017 and 2050, makassar city

\section{PENDAHULUAN}

Limpasan permukaan adalah perbandingan ant ara aliran permukaan dengan volume hujan yang jatuh (Subarkah, 1980; Wahyuningrum, 2007). Limpasan permukaan disimbolkan dengan huruf $C$, nilai $C$ dapat dijadikan sebagai indikator gangguan fisik pada suatu daerah aliran sungai (DAS), kesalahan dalam menentukan nilai $\mathrm{C}$ akan berakibat pada kesalahan perhitungan debit banjir rancangan pada suatu wilayah (Zope, Eldho, dkk, 2016; Zope,

\footnotetext{
${ }^{1}$ Departemen Arsitektur, Fakultas Teknik, Universitas Hasanuddin

${ }^{2}$ Labo. Pengembangan Kawasan Tepian Air, Fakultas Teknik, Universitas Hasanuddin

${ }^{3}$ Labo. Perenc. dan Sistem Informasi Kehutanan, Fakultas Kehutanan, Universitas Hasanuddin
} 
Eldho, 2016; Ali, Hadi, dkk, 2016). Semakin kedap suatu permukaan tanah, maka semakin tinggi nilai koefisien limpasannya (Palar, Wuisan, 2013).

Faktor-faktor yang mempengaruhi limpasan permukaan adalah elemen meteorologi seperti jenis presipitasi, intensitas curah hujan, dan lamanya curah hujan (Sriwati, 2014; Solikin, Suhartanto, 2017) sedangkan elemen daerah pengaliran seperti kondisi penggunaan lahan dan tutupan lahan, daerah pengaliran (kerapatan pengaliran), kondisi topografi, dan jenis tanah (Febryanto, 2016; Aurdin, 2014; Purwono, 2013; Takeda, 1983; Zhang et al., 2017). Ada beberapa metode yang dapat digunakan untuk menghitung koefisien limpasan permukaan diantaranya metode United States Forest Service, Hassing, dan Cook, dalam penelitian ini digunakan metode Cook karena memiliki nilai estimasi debit puncak yang lebih baik dibandingkan dengan metode lainnya (Samaawa, 2016).

Penelitian ini bertujuan untuk menganalisis koefisien limpasan permukaan (C) pada lokasi penelitian menggunakan peta penggunaan lahan dan tutupan lahan tahun 2017 dan tahun 2050.

\section{METODE}

\section{Lokasi Penelitian}

Penelitian dilaksanakan di Kota Makassar dengan batasan wilayah kecamatan yang mempunyai garis pantai yaitu Kecamatan Biringkanaya, Talamanrea, Tallo, Ujung Tanah, Wajo, Ujung Pandang, Mariso, dan Tamalate. Peta lokasi penelitian seperti ditunjukkan pada Gambar 1.

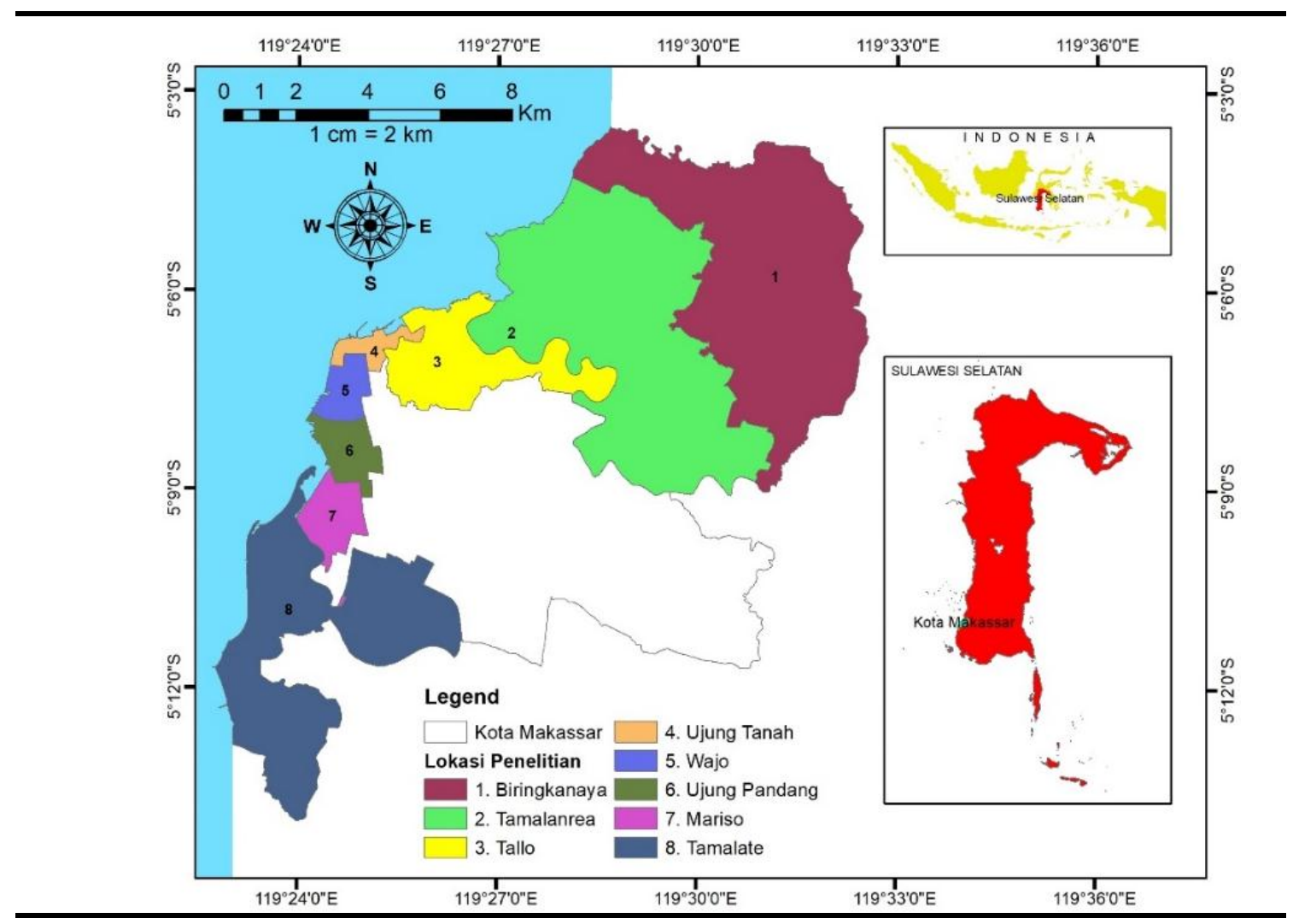

Gambar 1. Lokasi Penelitian 


\section{Data Penelitian}

Peta penggunaan lahan dan tutupan lahan Tahun 2017 bersumber dari hasil analisis citra landsat berbasis sistem informasi geografi (SIG), sedangkan peta Tahun 2050 merupakan hasil prediksi berbasis Agent-Based Model (ABM) pada aplikasi NetLogo. Peta seperti ditunjukkan pada Gambar 2 dan 3.

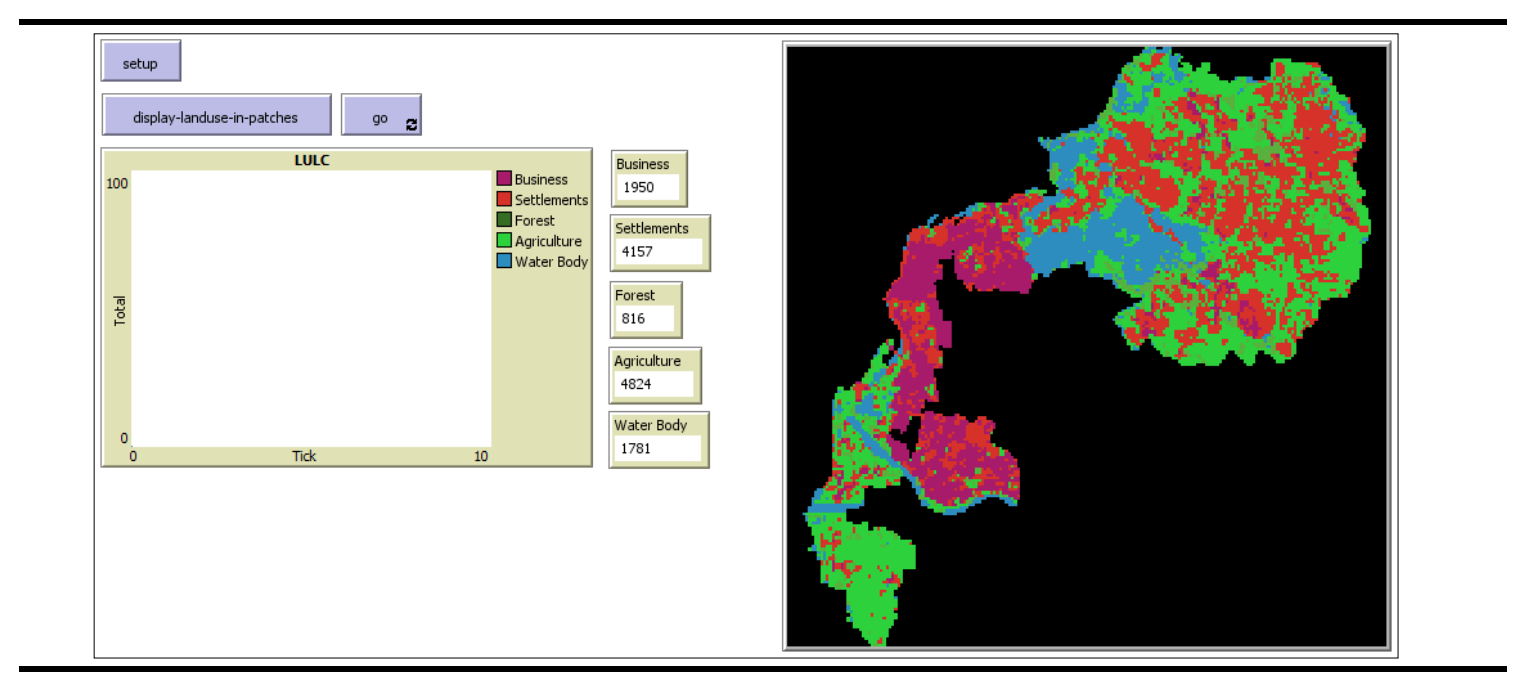

Gambar 2. Peta Penggunaan lahan dan tutupan lahan, 2017

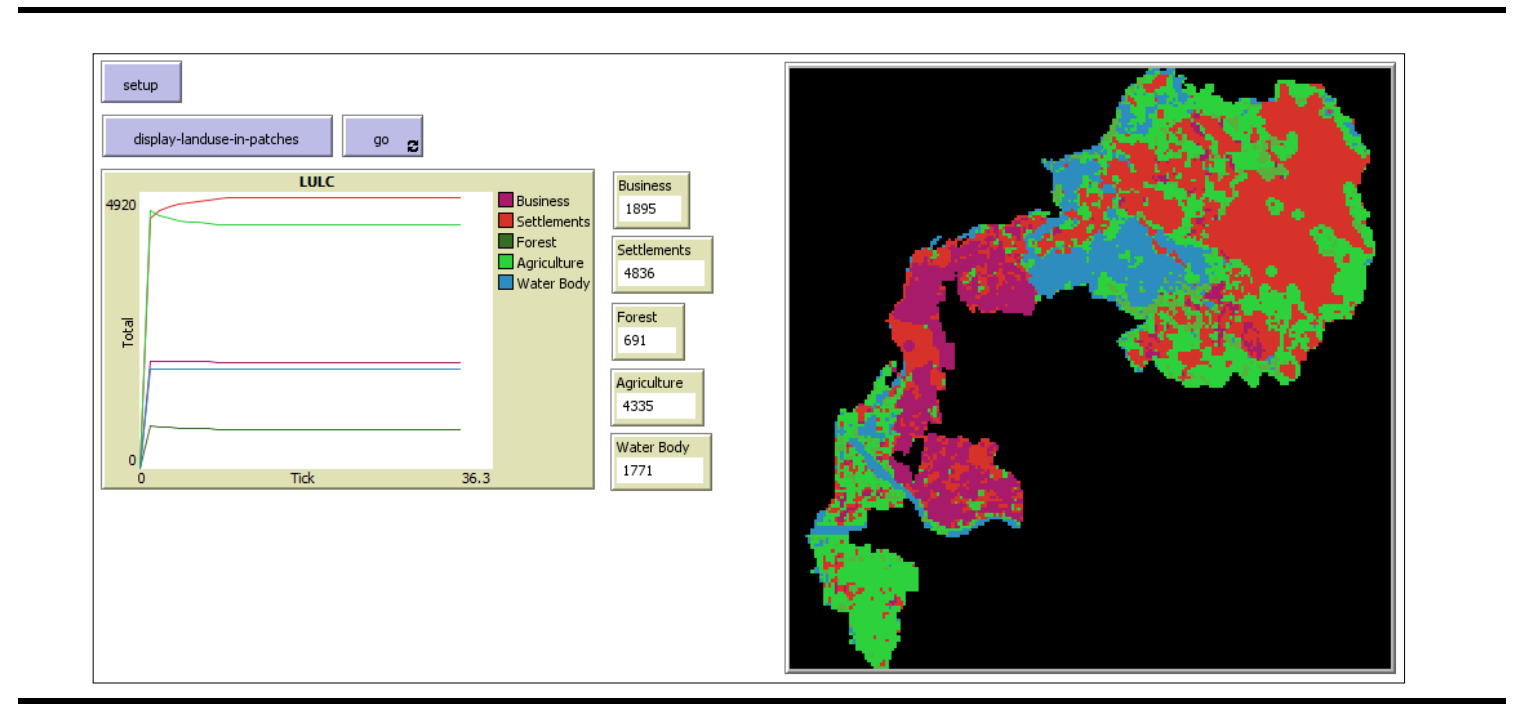

Gambar 3. Peta Penggunaan lahan dan tutupan lahan, 2050

Tabel 1 adalah informasi mengenai Gambar 2 dan 3, yang menunjukkan luas masingmasing kelas lahan.

Tabel 1. Klasifikasi penggunaan lahan dan tutupan lahan

\begin{tabular}{rlrrrr}
\multirow{2}{*}{ No. } & \multirow{2}{*}{ Klasifikasi } & \multicolumn{2}{c}{ Tahun 2017 } & \multicolumn{2}{c}{ Tahun 2050 } \\
\cline { 3 - 5 } & & Luas (Ha) & Persen (\%) & \multicolumn{1}{c}{ Luas (Ha) } & Persen (\%) \\
\hline 1 & Bisnis & $1,708.01$ & 14.41 & $1,659.83$ & 14.01 \\
2 & Permukiman & $3,641.12$ & 30.73 & $4,235.85$ & 35.75 \\
3 & Hutan & 714.73 & 6.03 & 605.25 & 5.11 \\
4 & Pertanian & $4,225.34$ & 35.66 & $3,797.03$ & 32.04 \\
5 & Tubuh Air & $1,559.98$ & 13.17 & $1,551.22$ & 13.09
\end{tabular}


Peta kemiringan lereng, bersumber dari hasil analisis spasial berbasis sistem informasi geografis (SIG) dengan memanfaatkan data ASTER-GDEM (Advanced Spaceborne Thermal Emission and Reflection Radiometer - Global Digital Elevation Model) akuisisi Oktober 2011 yang diperoleh melalui situs USGS. Peta lereng dibagi dalam 3 kategori yaitu 0-2\%, 2-5\% dan 5-8\% seperti ditunjukkan pada Gambar 4.

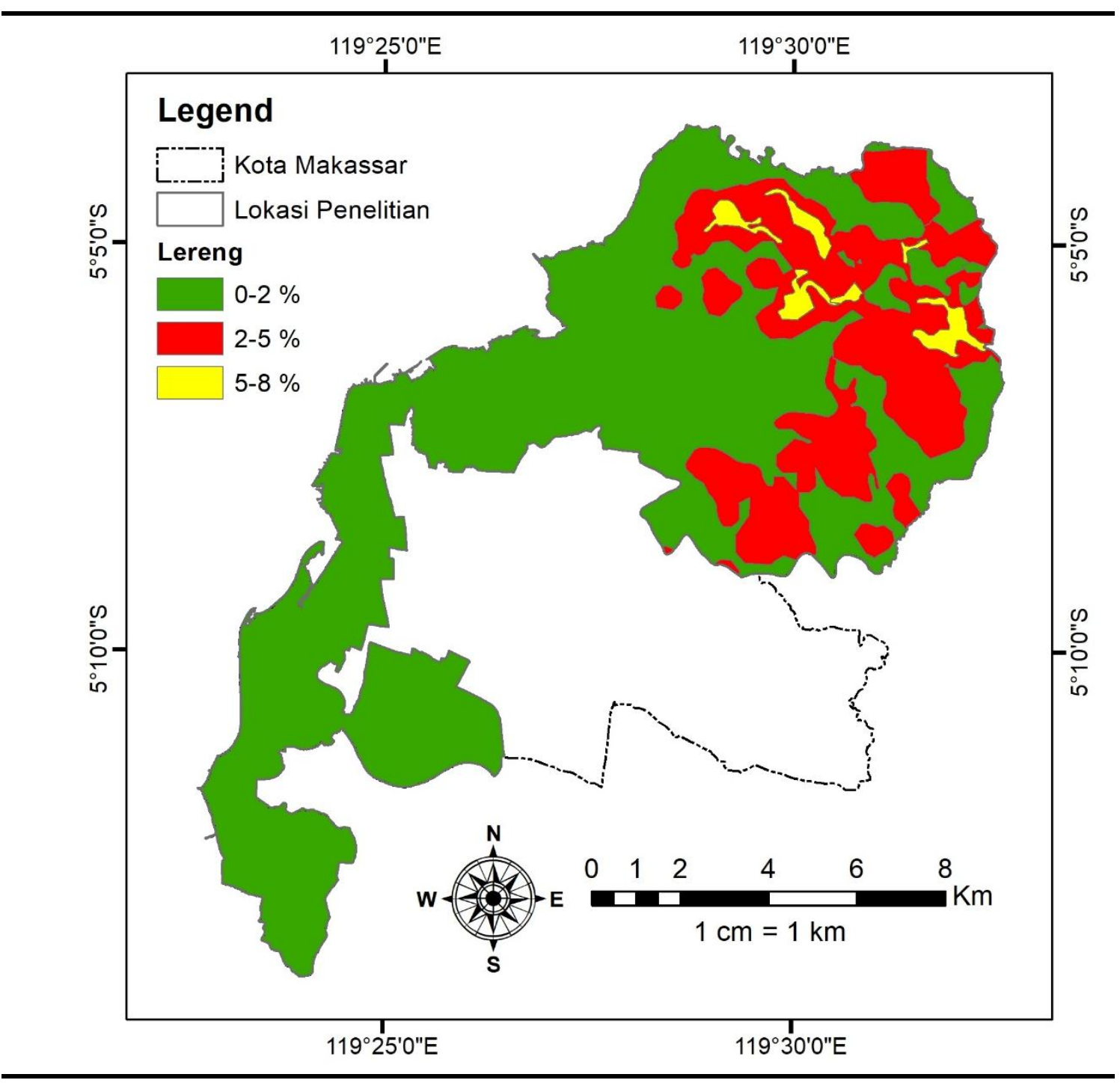

Gambar 4. Peta Kemiringan Lereng

Luas masing-masing kelas kemiringan lereng pada Gambar 4, diinformasikan pada Tabel 2.

Tabel 2. Klasifikasi Kemiringan Lereng

\begin{tabular}{cccrr}
\hline No. & Lereng (\%) & Topografi & Luas (Ha) & Persen (\%) \\
\hline 1 & $0-2$ & Datar & $8,636.86$ & 72.89 \\
2 & $2-5$ & Datar & $2,947.83$ & 24.88 \\
3 & $5-8$ & Sedang & 264.49 & 2.23 \\
& & Total & $11,849.18$ & 100 \\
\hline
\end{tabular}


Jenis tanah, sangat berpengaruh terhadap limpasan permukaan (Pathak, Chandrasekhar, dkk, 2016). Peta jenis tanah bersumber dari peta RTRW Kota Makassar 2010-2030. Pada lokasi penelitian, terdapat 2 jenis tanah yaitu Inceptisol dan Ultisol seperti ditunjukkan pada Gambar 5.

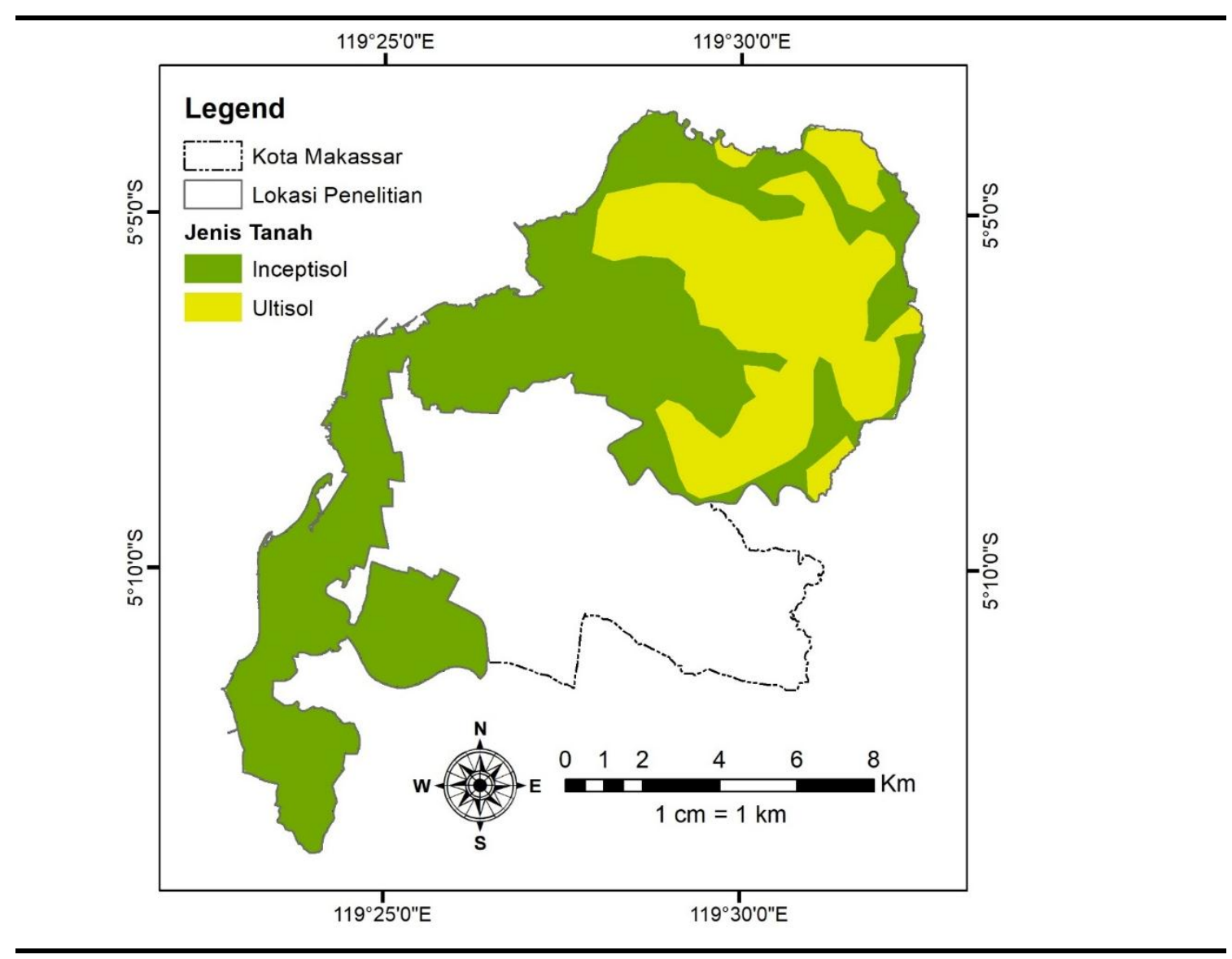

Gambar 5. Peta Jenis Tanah

Tabel 3 adalah informasi mengenai luas masing-masing jenis tanah pada objek penelitian berdasarkan Gambar 5.

Tabel 3. Klasifikasi Jenis Tanah

\begin{tabular}{clrrr}
\hline No. & Jenis tanah & Tekstur & Luas (Ha) & Persen (\%) \\
\hline 1 & Inceptisol & Pasir bergeluh & $8,055.85$ & 67.99 \\
2 & Ultisol & Geluh berlempung & $3,793.33$ & 32.01 \\
Total & & & $11,849.18$ & 100 \\
\hline
\end{tabular}

\section{Teknik Analisis}

Dalam (Samaawa, 2016), dijelaskan bahwa terdapat tiga metode untuk menentukan koefisien limpasan $(\mathrm{C})$ diantaranya adalah metode Hassing, metode United States Forest Service, dan metode Cook. Dalam penelitian ini, digunakan metode Cook untuk menentukan koefisien limpasan permukaan dengan peta penggunaan lahan dan tutupan lahan Tahun 2017 dan 2050.

Koefisien limpasan dengan metode Cook diperoleh dengan penggabungan beberapa karakteristik fisik daerah aliran sungai yang terdiri dari topografi, infiltrasi tanah, vegetasi 
dan simpanan permukaan. Masing-masing karakteristik fisik memiliki klasifikasi dengan bobot yang berbeda seperti yang terdapat pada Tabel 4 .

Tabel 4. Karakteristik DAS untuk metode Cook

\begin{tabular}{|c|c|c|c|c|}
\hline \multirow{2}{*}{$\begin{array}{c}\text { Karakteristik fisik } \\
\text { DAS } \\
\end{array}$} & \multicolumn{4}{|c|}{ Karakteristik yang menghasilkan aliran } \\
\hline & Ekstrim (100) & Tinggi (75) & Sedang (50) & Rendah (25) \\
\hline Topografi & Curam $(>40 \%)$ & $\begin{array}{l}\text { Berbukit } \\
(10 \%-30 \%)\end{array}$ & $\begin{array}{l}\text { Sedang } \\
(5 \%-10 \%)\end{array}$ & $\begin{array}{l}\text { Datar } \\
(0 \%-5 \%)\end{array}$ \\
\hline Bobot & 40 & 30 & 20 & 10 \\
\hline Infiltrasi Tanah & $\begin{array}{l}\text { Batuan yang } \\
\text { tertutup lapisan } \\
\text { tanah tipis }\end{array}$ & Lempung & $\begin{array}{l}\text { Geluh berpasir, } \\
\text { Geluh berdebu, } \\
\text { Geluh, Geluh } \\
\text { berlempung }\end{array}$ & $\begin{array}{l}\text { Pasir, Pasir } \\
\text { bergeluh }\end{array}$ \\
\hline Bobot & 20 & 15 & 10 & 5 \\
\hline Vegetasi penutup & $\begin{array}{l}\text { Permukiman, } \\
\text { Lahan kosong }\end{array}$ & $\begin{array}{l}\text { Sawah irigasi, Sawah } \\
\text { tadah hujan, dan }\end{array}$ & $\begin{array}{l}\text { Kebun campuran, } \\
\text { Hutan kurang rapat }\end{array}$ & Hutan rapat \\
\hline Bobot & & Tegalan & & \\
\hline & 20 & 15 & 10 & 5 \\
\hline $\begin{array}{l}\text { Simpanan } \\
\text { permukaan }\end{array}$ & $\begin{array}{l}\text { Dapat diabaikan, } \\
\text { Pengatusan kuat, } \\
\text { Saluran curam, } \\
\text { Tidak ada danau }\end{array}$ & $\begin{array}{l}\text { Sedikit, Pengatusan } \\
\text { baik, Tidak ada } \\
\text { danau }\end{array}$ & $\begin{array}{l}\text { Sedang, Pengatusan } \\
\text { baik-sedang, } 2 \% \text { luas } \\
\text { daerah berupa danau } \\
10\end{array}$ & $\begin{array}{l}\text { Banyak, } \\
\text { Pengatusan } \\
\text { kurang, Banyak } \\
\text { danau }\end{array}$ \\
\hline Bobot & 20 & 15 & & 5 \\
\hline
\end{tabular}

Sumber: Samaawa, 2016

Untuk menghitung koefisien limpasan permukaan dengan metode Cook digunakan persamaan sebagai berikut:

$C D A S=\frac{C 1 A 1+C 2 A 2+C n A n}{A 1+A 2+A 3}$

Dimana:

C : koefisien limpasan

$\mathrm{C} 1,2, \mathrm{n} \quad$ : koefisien aliran parameter

$\mathrm{A} 1,2, \mathrm{n} \quad$ : luas parameter

\section{HASIL DAN PEMBAHASAN}

Koefisien limpasan permukaan yang dihasilkan dalam penelitian ini ada 2 (dua) yaitu koefisien yang berdasarkan pada peta penggunaan lahan dan tutupan lahan tahun 2017 dan tahun 2050. Variabel topografi, infiltrasi tanah, vegetasi penutup dan simpanan permukaan adalah tetap untuk perhitungan koefisien limpasan tahun 2017 dan 2050. Pada tabel 5 diinformasikan analisis koefisien limpasan permukaan untuk Tahun 2017.

Tabel 5. Koefisien limpasan permukaan Tahun 2017

\begin{tabular}{|c|c|c|c|c|c|c|c|c|c|c|c|c|}
\hline \multirow{3}{*}{$\begin{array}{l}\mathrm{N} \\
\mathrm{o} .\end{array}$} & \multirow{3}{*}{$\begin{array}{c}\text { Karakteris } \\
\text { tik DAS }\end{array}$} & \multicolumn{8}{|c|}{ Karakteristik yang menghasilkan aliran } & \multirow{3}{*}{$\begin{array}{l}\text { Bobot } \\
\mathrm{x} \text { Luas }\end{array}$} & \multirow{3}{*}{$\begin{array}{l}\text { Total } \\
\text { Luas } \\
(\mathrm{Ha})\end{array}$} & \multirow{3}{*}{$\begin{array}{c}\text { Nilai } \\
\text { C }\end{array}$} \\
\hline & & \multicolumn{2}{|c|}{ Ekstrim } & \multicolumn{2}{|c|}{ Tinggi } & \multicolumn{2}{|c|}{ Sedang } & \multicolumn{2}{|c|}{ Rendah } & & & \\
\hline & & $\begin{array}{c}\text { Bob } \\
\text { ot }\end{array}$ & $\begin{array}{l}\text { Luas } \\
(\mathrm{Ha})\end{array}$ & $\begin{array}{c}\text { Bob } \\
\text { ot }\end{array}$ & $\begin{array}{l}\text { Luas } \\
(\mathrm{Ha})\end{array}$ & $\begin{array}{c}\text { Bob } \\
\text { ot }\end{array}$ & $\begin{array}{l}\text { Luas } \\
(\mathrm{Ha})\end{array}$ & $\begin{array}{c}\text { Bob } \\
\text { ot }\end{array}$ & $\begin{array}{l}\text { Luas } \\
(\mathrm{Ha})\end{array}$ & & & \\
\hline $\mathrm{a}$ & $\mathrm{b}$ & c & $\mathrm{d}$ & $\mathrm{e}$ & $\mathrm{F}$ & $\mathrm{g}$ & $\mathrm{h}$ & $\mathrm{i}$ & $\mathrm{j}$ & $\begin{array}{c}\mathrm{k}=\mathrm{c}^{\star} \mathrm{d} \\
+\mathrm{e}^{\star} \mathrm{f}+ \\
\mathrm{g}^{\star} \mathrm{h}+\mathrm{i} \\
{ }_{\star j}\end{array}$ & $\begin{array}{c}\mathrm{l}=\mathrm{d}+\mathrm{f}+\mathrm{h} \\
+\mathrm{j}\end{array}$ & $\begin{array}{c}\mathrm{m}=\mathrm{k} \\
/ \mathrm{l}\end{array}$ \\
\hline 1 & Topografy & 0,40 & 0,00 & 0,30 & 0,00 & 0,20 & 264,49 & 0,10 & $\begin{array}{c}11.584 \\
, 69\end{array}$ & $\begin{array}{c}1.211, \\
37\end{array}$ & $\begin{array}{c}11.849,1 \\
8\end{array}$ & $\begin{array}{c}0,10 \\
22\end{array}$ \\
\hline 2 & $\begin{array}{l}\text { Infiltrasi } \\
\text { Tanah }\end{array}$ & 0,20 & 0,00 & 0,15 & 0,00 & 0,10 & $\begin{array}{c}3.793 \\
33\end{array}$ & 0,05 & $\begin{array}{c}8.055 \\
85\end{array}$ & 782,13 & $\begin{array}{c}11.849,1 \\
8\end{array}$ & $\begin{array}{c}0,06 \\
60\end{array}$ \\
\hline 3 & $\begin{array}{l}\text { Vegetasi } \\
\text { Penutup }\end{array}$ & 0,20 & $\begin{array}{c}6.909 \\
11\end{array}$ & 0,15 & 0,00 & 0,10 & $\begin{array}{c}4.225 \\
34\end{array}$ & 0,05 & 714,73 & $\begin{array}{c}1.528 \\
10\end{array}$ & $\begin{array}{c}11.849,1 \\
8\end{array}$ & $\begin{array}{c}0,15 \\
52\end{array}$ \\
\hline
\end{tabular}




\begin{tabular}{|c|c|c|c|c|c|c|c|c|c|c|c|c|}
\hline \multirow{3}{*}{$\begin{array}{l}\mathrm{N} \\
\mathrm{o}\end{array}$} & \multirow{3}{*}{$\begin{array}{c}\text { Karakteris } \\
\text { tik DAS }\end{array}$} & \multicolumn{8}{|c|}{ Karakteristik yang menghasilkan aliran } & \multirow{3}{*}{$\begin{array}{l}\text { Bobot } \\
\mathrm{x} \text { Luas }\end{array}$} & \multirow{3}{*}{$\begin{array}{l}\text { Total } \\
\text { Luas } \\
(\mathrm{Ha})\end{array}$} & \multirow{3}{*}{$\begin{array}{c}\text { Nilai } \\
\text { C }\end{array}$} \\
\hline & & \multicolumn{2}{|c|}{ Ekstrim } & \multicolumn{2}{|c|}{ Tinggi } & \multicolumn{2}{|c|}{ Sedang } & \multicolumn{2}{|c|}{ Rendah } & & & \\
\hline & & $\begin{array}{l}\text { Bob } \\
\text { ot }\end{array}$ & $\begin{array}{l}\text { Luas } \\
\text { (Ha) }\end{array}$ & $\begin{array}{l}\text { Bob } \\
\text { ot }\end{array}$ & $\begin{array}{l}\text { Luas } \\
\text { (Ha) }\end{array}$ & $\begin{array}{l}\text { Bob } \\
\text { ot }\end{array}$ & $\begin{array}{l}\text { Luas } \\
\text { (Ha) }\end{array}$ & $\begin{array}{c}\text { Bob } \\
\text { ot }\end{array}$ & $\begin{array}{l}\text { Luas } \\
\text { (Ha) }\end{array}$ & & & \\
\hline \multirow[t]{2}{*}{4} & $\begin{array}{l}\text { Simpanan } \\
\text { Permukaa } \\
n\end{array}$ & 0,20 & 0,00 & 0,15 & $\begin{array}{c}11.849 \\
, 18\end{array}$ & 0,10 & 0,00 & 0,05 & 0,00 & $\begin{array}{c}1.184, \\
92\end{array}$ & $\begin{array}{c}11.849,1 \\
8\end{array}$ & $\begin{array}{c}0,15 \\
00\end{array}$ \\
\hline & & & & & & & & & & & Total & $\begin{array}{c}0,47 \\
34\end{array}$ \\
\hline
\end{tabular}

Hasil analisis menunjukkan bahwa nilai $C$ yang diperoleh pada tahun 2017 adalah 0.4734 , artinya bahwa $47,34 \%$ air hujan yang jatuh pada objek penelitian akan menjadi aliran permukaan.

Sedangkan pada tahun 2050, nilai koefisien limpasan permukaan (C) sebesar 0,4785 atau dapat dinyatakan bahwa 47,85\% air hujan yang jatuh pada objek penelitian menjadi aliran permukaan, seperti diinformasikan pada tabel 6.

Tabel 6. Koefisien limpasan permukaan Tahun 2050

\begin{tabular}{|c|c|c|c|c|c|c|c|c|c|c|c|c|}
\hline \multirow{3}{*}{$\begin{array}{l}\mathrm{N} \\
\mathrm{o}\end{array}$} & \multirow{3}{*}{$\begin{array}{l}\text { Karakteristik } \\
\text { DAS }\end{array}$} & \multicolumn{8}{|c|}{ Karakteristik yang menghasilkan aliran } & \multirow{3}{*}{$\begin{array}{l}\text { Bobot } \\
\text { x Luas }\end{array}$} & \multirow{3}{*}{$\begin{array}{l}\text { Total } \\
\text { Luas } \\
(\mathrm{Ha})\end{array}$} & \multirow{3}{*}{$\begin{array}{c}\text { Nilai } \\
\text { C }\end{array}$} \\
\hline & & \multicolumn{2}{|c|}{ Ekstrim } & \multicolumn{2}{|c|}{ Tinggi } & \multicolumn{2}{|c|}{ Sedang } & \multicolumn{2}{|c|}{ Rendah } & & & \\
\hline & & $\begin{array}{l}\text { Bob } \\
\text { ot }\end{array}$ & $\begin{array}{c}\text { Luas } \\
(\%)\end{array}$ & $\begin{array}{l}\text { Bob } \\
\text { ot }\end{array}$ & $\begin{array}{c}\text { Luas } \\
(\%)\end{array}$ & $\begin{array}{c}\text { Bob } \\
\text { ot }\end{array}$ & Luas $(\%)$ & $\begin{array}{c}\text { Bob } \\
\text { ot }\end{array}$ & Luas (\%) & & & \\
\hline $\mathrm{a}$ & b & c & d & $\mathrm{e}$ & $\mathrm{F}$ & g & $\mathrm{h}$ & $\mathrm{i}$ & $\mathrm{j}$ & $\begin{array}{c}\mathrm{k}=\mathrm{c}^{\star} \mathrm{d} \\
+\mathrm{e}^{\star} \mathrm{f}+ \\
\mathrm{g}^{\star} \mathrm{h}+\mathrm{i} \\
\star_{\mathrm{j}}\end{array}$ & $\begin{array}{c}\mathrm{l}=\mathrm{d}+\mathrm{f}+\mathrm{h} \\
+\mathrm{j}\end{array}$ & $\begin{array}{c}\mathrm{m}=\mathrm{k} \\
/ \mathrm{l}\end{array}$ \\
\hline 1 & Topografy & 0,40 & 0,00 & 0,30 & 0,00 & 0,20 & 264,49 & 0,10 & $11.584,69$ & $\begin{array}{r}1.211 \\
37\end{array}$ & $\begin{array}{r}11.849,1 \\
8\end{array}$ & $\begin{array}{r}0,10 \\
22\end{array}$ \\
\hline 2 & $\begin{array}{l}\text { Infiltrasi } \\
\text { Tanah }\end{array}$ & 0,20 & 0,00 & 0,15 & 0,00 & 0,10 & $3.793,33$ & 0,05 & $8.055,85$ & 782,13 & $\begin{array}{r}11.849,1 \\
8\end{array}$ & $\begin{array}{r}0,06 \\
60 \\
\end{array}$ \\
\hline 3 & $\begin{array}{l}\text { Vegetasi } \\
\text { Penutup }\end{array}$ & 0,20 & $\begin{array}{r}7.446 \\
90\end{array}$ & 0,15 & 0,00 & 0,10 & $3.797,03$ & 0,05 & 605,25 & $\begin{array}{r}1.589 \\
10 \\
\end{array}$ & $\begin{array}{r}10.297,9 \\
6\end{array}$ & $\begin{array}{r}0,16 \\
03 \\
\end{array}$ \\
\hline 4 & $\begin{array}{l}\text { Simpanan } \\
\text { Permukaan }\end{array}$ & 0,20 & 0,00 & 0,15 & $\begin{array}{r}11.849 \\
, 18 \\
\end{array}$ & 0,10 & 0,00 & 0,05 & 0,00 & $\begin{array}{r}1.777 \\
38\end{array}$ & $\begin{array}{r}11.849,1 \\
8\end{array}$ & $\begin{array}{r}0,15 \\
00 \\
\end{array}$ \\
\hline & & & & & & & & & & & Total & $\begin{array}{r}0,47 \\
85 \\
\end{array}$ \\
\hline
\end{tabular}

Pada dasarnya nilai koefisien limpasan permukaan untuk tiap-tiap jenis penggunaan lahan sudah ditentukan oleh beberapa pakar seperti dalam buku "Hidrologi Untuk Perencanaan Bangunan Air" (Subarkah, 1980) dan "Hidrologi Terapan" (Triatmodjo, 2013). Umumnya untuk kebutuhan perencanaan bangunan air seperti bendung, jaringan irigasi, drainase dapat digunakan nilai $C$ yang sudah ditentukan.

Dalam penelitian ini, nilai koefisien limpasan permukaan (C) dihitung secara khusus untuk membandingkan pengaruh perubahan penggunaan lahan dan tutupan lahan terhadap nilai C pada tahun 2017 dan 2050.

\section{KESIMPULAN}

Metode Cook adalah salah satu metode yang dapat digunakan untuk menganalisis koefisien limpasan permukaan (C), parameter yang diukur adalah topografi, jenis tanah, tutupan lahan dan simpanan permukaan, pembobotan dilakukan terhadap masing-masing karakteristik daerah aliran sungai yang menghasilkan aliran. Dalam penelitian ini, paramater tutupan lahan terdiri dari peta 2017 dan 2050. Hasil penelitian menunjukkan bahwa pada tahun 2017, nilai koefisien limpasan permukaan (C) sebesar 0.4734 dan untuk tahun 2050 diperoleh nilai $(C)$ sebesar 0.4785 . Angka-angka tersebut menunjukkan bahwa pada saat terjadi hujan, air akan menjadi aliran permukaan sebesar 47.34 persen pada tahun 2017 dan 47.85 persen untuk tahun 2050. 


\section{UCAPAN TERIMA KASIH}

Peneliti mengucapkan terima kasih kepada ESRI Indonesia yang turut mendukung pelaksanaan penelitian dengan bantuan software berbasis sistem informasi geografis (SIG) versi 10.5 .

\section{REFERENSI}

Ali, M., Hadi, S., \& Sulistyantara, B. (2016). Study on land cover change of Ciliwung downstream watershed with spatial dynamic approach. Procedia - Social and Behavioral Sciences, 227(November 2015), 52-59. https://doi.org/10.1016/j.sbspro.2016.06.042

Aurdin. (2014). Pengaruh Perubahan Tata Guna Lahan Terhadap Karakteristik Hidrograf Banjir (Studi Kasus DAS Dengkeng dan DAS Jlantah Bagian Hulu Bengawan Solo Kabupaten Sukoharjo, Provinsi Jawa Tengah). Tekno Global, III(1).

Febryanto. (2016). Pengaruh Perubahan Penggunaan Lahan Terhadap Debit Puncak Sub-DAS Opak Hulu Tahun 2009 dan 2014 Menggunakan Citra Landsat 5 dan Landsat 8. Jurnal Bumi Indonesia, 5, 1-10.

Palar, Wuisan, T. (2013). Studi Perbandingan Antara Hidrograf SCS (Soil Conservation Service) dan Metode Rasional Pada DAS Tikala. Jurnal Sipil Statik, 1, 171-176.

Pathak, P., Chandrasekhar, K., Wani, S. P., Rao, R., \& Budama, N. (2016). Integrated runoff and soil loss monitoring unit for small agricultural watersheds. Computers and Electronics in Agriculture, 128, 50-57. https://doi.org/10.1016/j.compag.2016.08.011

Purwono, N. (2013). Pemodelan Spasial Untuk Identifikasi Banjir Genangan Di Wilayah Kota Surakarta Dengan Pendekatan Metode Rasional (Rational Runoff Method).

Samaawa, H. (2016). Estimasi Debit Puncak Berdasarkan Beberapa Metode Penentuan Koefisien Limpasan di Sub DAS Kedung Gong, Kabupaten Kulonprogo, Yogyakarta. Jurnal Bumi Indonesia, 5.

Solikin, Suhartanto, H. (2017). Penanganan Genangan Dengan Sistem Polder pada Wilayah Kota Banjarmasin. Teknik Pengairan, 8, 15-25.

Sriwati. (2014). Studi Pengaruh Perubahan Tata Guna Lahan Terhadap Infrastruktur Jaringan Drainase Kota Rantepao. Forum Bangunan, 12.

Subarkah, I. (1980). Hidrologi Untuk Perencanaan Bangunan Air (Cetakan Ke). Bandung: Angkasa Offset.

Takeda, K. (1983). Hidrologi Untuk Pengairan. (S. Sosrodarsono, Ed.). Jakarta.

Triatmodjo, B. (2013). Hidrologi Terapan (Ketiga). Yogyakarta: Beta Offset Yogyakarta.

Wahyuningrum, P. (2007). Aplikasi Sistem Informasi Geografis Untuk Perhitungan Koefisien Aliran Permukaan di Sub DAS Ngunut I, Jawa Tengah. Penelitian Hutan Dan Konservasi Alam, No. 6, 561-571.

Zhang, F. B., Bai, Y. J., Xie, L. Y., Yang, M. Y., Li, Z. B., \& Wu, X. R. (2017). Runoff and soil loss characteristics on loess slopes covered with aeolian sand layers of different thicknesses under simulated rainfall, 549, 244-251. https://doi.org/10.1016/j.jhydrol.2017.04.002

Zope, Eldho, J. (2016). Impacts of land use-land cover change and urbanization on flooding: A case study of Oshiwara River Basin in Mumbai, India. Catena, 145, 142-154. https://doi.org/10.1016/j.catena.2016.06.009

Zope, P. E., Eldho, T. I., \& Jothiprakash, V. (2016). Catena Impacts of land use - land cover change and urbanization on fl ooding: A case study of Oshiwara River Basin in Mumbai , India. Catena, 145, 142154. https://doi.org/10.1016/j.catena.2016.06.009 